\title{
"I would invite her to play with me" Fostering respect, care and participation in a preschool: An action research project
}

\author{
Patricia Segura Valdes and Jórunn Elídóttir \\ Abstract \\ - Um höfundana \\ About the authors \\ - Heimildir
}

This article reports an action research (AR) project on how democratic values implemented in teaching, promote the awareness and sensitivity of social values. The research aimed to awaken children's awareness of democratic values and to observe effective ways of teaching them. The research analyzed children's sensitivity to respect, care, and participation. Furthermore, it investigated children's construction of values. The research was conducted in Iceland from 2017-2018 and involved 27 five to sixyear-old children participating as co-researchers, nine teachers, co-researchers, and the investigator. Data collected included: reading values-based literature, children's drawings, session record, discussions leading from moral dilemmas, play, and observation.

The findings showed that children's awareness of democratic values grows with the use of value-based literature. The children used their drawings to assimilate, construct and negotiate developing values. Exposure to moral dilemmas allowed children and teachers to negotiate their values and here the teacher role-model was essential. Children considered play as the most enjoyable way to learn, and they liked teachers to participate.

This article shares one part of the findings that reveal the benefits of using democratic methodologies with the children in light of John Dewey's theory. The children generated rich and ingenious ideas about values and their significance, expressing enthusiasm towards opportunities to make decisions that matter to them.

The study provides important insights into how organized preschool activities can increase children's awareness of the democratic values present in their daily lives. Preschools place great emphasis on democratic values in their work and it is therefore important to develop methods and resources to strengthen children's awareness and knowledge in this field.

Keywords: Democracy, respect, care participation, action research

\section{How can I improve my teaching of democratic values?}

The subject idea came about during the time the first author was studying in Iceland at the University of Akureyri (UNAK) and the second author was the supervisor, so the article will refer to the first author in first person. The lessons, overall, focused on students with special needs with an emphasis on their rights. Throughout my youth in Mexico, I learned to obey adults including teachers. Respect was a sign of a good upbringing, care was a sign of philanthropy, and participation was work rather than to be involved. None of those concepts were social tools 
used to facilitate and improve social behavior. I have worked as a teacher since I was 17 years old, and my teachers had a large role in shaping my teaching style. In 1989 I moved to Iceland and attended the University of Iceland and began my career as a teacher in Spanish literature. I could organize the teaching within the class time, make assessments, and create good ethical behavior in a student-teacher relationship. Nevertheless, the theoretical underlying of it all was unknown to me. I had diverse experiences during my study at UNAK regarding the use of democratic values in the relationship between student and teacher. Education Values took a more substantial place in my life as a student and as a teacher. Considering democratic education and values are significant parts of the Icelandic Curriculum for Preschool in Iceland (Mennta- og menningarmálaráðuneytið, 2011). I decided to study whether I could transfer that learning to my teaching style and how that would impact my students. I wondered how children could learn values and whether they would recognize them daily. My research question was: How can I improve my teaching regarding democratic values implicitly known to children?

The aim of the MA research was to awaken children's awareness of democratic values, respect, care and participation, and to observe effective ways of using age-appropriate texts, teacher-led discussions, drawings and group interviews in the teaching of those values. I chose a limited number of concepts to frame the length of the AR for children not to lose interest. The AR sessions were held from February to March 2019. This article shares some of the findings of the research that show the benefits of using democratic methodologies with the children in light of John Dewey's theory. The study provides an insight into how organized preschool activities can build up children's awareness of the democratic values that are present in their daily lives and is, as such, a contribution to the discussion regarding children's learning of concepts allied to values.

\section{Theoretical frame}

Different pedagogical traditions have shaped preschool development and molded the preschool system in Iceland (Jón Torfi Jónasson, 2006). A focus on base-development, child-centered care has been characteristic of Icelandic preschools from the start. In recent years, Noddings' ideas of care have had a substantial impact on early childhood education (Jóhanna Einarsdóttir, 2007). John Dewey's theory of including democratic values in education has also been significant in the development of Icelandic preschools and it is recognized as one of the pillars in education (Kristín Dýrfjörð, 2006; Ólafur Páll Jónsson, 2010; Valborg Sigurðardóttir, 1998).

The authors are aware that there is substantial literature and ongoing debate on the advantage of using concrete operational approaches to develop children's understanding of concepts and different theoretical and pragmatic approaches are to be found on this matter. This can be observed in the work of Fleer (2011) Piaget (1950/1954) Lovatt and Hedges (2015) and Marchand (2012) to name but a few. However, in this article the focus is on AR research and a selected theoretical approach, which in this context are utilized to illustrate the work with the children.

\section{The contributions of democracy to education}

Democratic theory is based on a complex ideology that involves individual rights and values. The etymology of democracy is composed of two words: dêmos, meaning people, and krátos, meaning power (Dahl, 2020). Incontestably, the fundamental principle of democracy is sovereignty being invested in the people (Davies, 1999). Democracy manifests itself in different ways from country to country, and not all philosophers have agreed as regards its social benefits (Christiano, 2006). Values attributed to democracy vary among countries; some of these are equality, justice and freedom (Christiano, 2006). On 20 ${ }^{\text {th }}$ November 1990 The Convention on the Rights of the Child was created and was signed by the government of Iceland on 26th January 1990 (Skrifstofa Alpingis, 2018). 
John Dewey imported tools of democratic theory into education and introduced new insights into the student-teacher relationship (1897/2010). According to Dewey (1916/1998), the school's purpose is to transmit ancestral knowledge and prepare citizens to gain more power over society; thus ensuring the continuity and development of knowledge (Dewey, 1916/1998, 1897/2010; Gunnar E. Finnbogason, 2010). Dewey (1897/2010) viewed schools as a democratic social nucleus with the purpose of educating citizens on the values that reign in society. According to him children should exercise, among other skills, self-assessment and self-agency, enabling them to perform in social unity and collaboration with others, thus finding a role with a social purpose. Teachers should choose activities that stimulate children's interest and work with them in a way that gives them a sense of approval from others.

Dewey's educational ideas are reflected in the Icelandic Preschool Curriculum for school functions and activities by encouraging preschools to perform as a democratic forum where all participants are respected. Their activities are grounded in equality, respect for human diversity, and multiculturalism (Mennta- og menningarmálaráðuneytið, 2011). Considering pragmatism philosophy, which advocates the practical efficiency of knowledge, Dewey explained that the school is an extension of a child's home, and its activities should be related to home activities (Ólafur Páll Jónsson, 2010).The practice of values is critical in the interaction of people and it is important for the creation of new values. (Dewey, 1916/1998). An inclusive school satisfies democratic requirements by encouraging equality teaching. This has had a positive influence in Iceland because it gives children the opportunity to attend school with their neighbors. Even though the Icelandic curriculum specifies that children's needs must be met at their school, not all schools fulfill the democratic purpose (Ólafur Páll Jónsson, 2016; Ólafur Páll Jónsson \& Póra Björg Sigurðardóttir, 2012).

Dewey (1916/1998) claimed that democracy is a way of life that encourages attitudes and facilitates human collaboration. In a democratic society, people have a common interest, they experience collectively, and they recognize one another's interest. People should also have a diversity of opinions, values, and cultural heritage (LaCelle-Petersson \& VanFossen, 1999). Therefore, in a democratic society, children must have the opportunity to practice discussion, critical thinking, and debate as Ólafur Páll Jónsson and Póra Björg Sigurðardóttir (2012), point out.

Democracy is needed in people's daily interactions and value judgments, because within conflict and conversation, people may find the common trends that bind them. Dewey saw the purpose of democracy in daily participation with friends, neighbors and family inside and outside the home. Opposition to democracy would be "intolerance, abuse, calling of names because of differences of opinion, religion, politics or business, as well as because of differences of race, color, wealth or culture which are treason to the democratic way of life" (LaCelle-Petersson \& VanFossen, 1999). The Icelandic curriculum encourages schools to be guided by values such as respect, participation, care, autonomy, sustainability, justice, and equality, among others (Mennta- og menningarmálaráđuneytið, 2011). Regarding democracy, Ólafur Páll Jónsson (2016) considers respecting the attitude or approach that Dewey describes as being essential for harmony among citizens in a democratic society.

\section{Respect}

Dewey (1916/1998) believed that the roots of democracy are in the individual's character, and that the school helps individuals to release their capacities to reach social goals. Values are a social phenomenon people learn from others, comprising knowledge that becomes part of an individual's personality (Páll Skúlason, 1990).

According to Kant (1785/1996), respect is not conditional on qualities or substance, but inherent, regardless of position, academic abilities, or qualities, and it is not a means to an end. His definition of respect is "act in such a way that you treat humanity, whether in your own person or the 
person of any other, never simply as a means but always at the same time as an end." Moreover, one of the keys to respect shown to be important is the recognition of others' needs and happiness when looking towards fulfilling one's own. People can find reasons to respect themselves, but this does not mean that others value those reasons and reciprocate the respect (Cureton, 2013).

Cureton (2013) proposes that self-respect is an important factor because it gives persons a reason to treat themselves with dignity and open the door for others to respect them as well (Cureton, 2013). In the same way, self-respect inspires children to participate and develop their qualities (Ólafur Páll Jónsson \& Póra Björg Sigurðardóttir, 2012). George (2009) shows in a cross-cultural analysis that people usually do not relate the above explanation of respect to young children. The element of respect seems not to be generalized to all ages, perhaps because people think that children are too dependent, too small, too immature, or too young. However, people should treat children with the same respect that they do others, because dignity is a common attribute due to all human beings (Ólafur Páll Jónsson \& Póra Björg Sigurðardóttir, 2012; United Nations Committee on the Rights of the Child, 2006). People must nurture, guide, care, and protect children in such a way that they feel respected in their individuality. In a school setting, respect is manifested when teachers pay attention to children, stop what they are doing to listen to what children have to say, demonstrate interest, and take them seriously (Sigrún Aðalbjarnardóttir, 2007).

The findings of a qualitative case study by Christie (2018) and a study by George (2009) show that when a teacher treats children with respect, gives them choices, time, and space, their self-esteem is nurtured, and their autonomy grows. According to Banks (2004), people should learn to respect others without losing their individuality by respecting themselves first. Selfrespect is to recognize one's ability and capacity, which nurtures the self-image (Maslow, 1943; Sigrún Aðalbjarnardóttir, 2007). Regarding preconception, Ólafur Páll Jónsson and Dóra Björg Sigurðardóttir (2012) state that involving students in moral discussion is among the things that lead them to reflect on an understanding of diversity. A four-year study relating to diversity conducted by the Multicultural Education Consensus Panel (Banks et al., 2001) concludes that schools must search for a means to respect diversity to gain students' trust in a unified society.

\section{Care}

Care is another value concept used in the current study. Stanford Encyclopedia defines care as an act of "meeting the needs of others within the personal relationship." Care can be an action, an attitude and can also be regarded as a virtue. According to Gheaus (2018) some theorists argue that care must be acknowledged as a universal value, since individuals depend on it at different stages in life, this being crucial for all at early and late ages. In a discussion of moral education Noddings (2010) defines care as a moral attitude that develops from an individual's early relationships and is projected into future relationships. It means being attentive because the caregiver shows attentiveness and receptiveness to other people's needs. The caregiver puts his own interest aside and prioritizes the needs of the cared-for individual.

As Noddings (2010) has noted, for the completion of this relationship, the cared-for person must recognize the efforts of the caregiver. Moreover, caring is demonstrated by giving children attention and creating closeness; this results in children feeling loved and safe (Jóhanna Einarsdóttir et al., 2015). Sigrún Aðalbjarnardóttir (2007) distinguishes between respect and care, stating that the first is distant and the second is close. She affirms that it is possible to respect a person without caring, but children need both. Children need to grow, both in feelings of independence and of closeness, the former to help them to develop their own person and the latter to help them to connect emotionally with others. Noddings (2005) explores caring relationships and encounters of education and points out three elements of care for pedagogical practice. Firstly, it must be cooperative and open to the children's point of view to gain their trust. Secondly, teachers must learn what their needs, working habits, interests, and talents are so they can build 
an individualized curriculum maintaining good and friendly conditions in the school for the children. Finally, when doing the above, teachers will expand their knowledge and competence.

Warm and sensitive interaction between children and teachers and a positive friendly organization in the classroom is also recommended in a review of research relating to the quality of ECE to children's outcomes conducted by Burchinal (2018). She emphasizes that when teachers care they help children with scaffolded interaction to enrich their vocabulary and acquire executive functioning skills. Within a caring relationship child grow in security and self-esteem and become more capable of showing kindness to those in need (Sigrún Aðalbjarnardóttir, 2007).

Democratic values are part of the Icelandic curriculum, and care is one of its fundamental pillars. These are intertwined in all preschool activities in Iceland since, according to the Icelandic curriculum, preschool practice and instruction must inter alia reflect values, care and respect (Mennta- og menningarmálaráðuneytið, 2011).

\section{Participation}

The third value in this study is participation, which means "to take part in an action" (MerriamWebster, n.d.). In a democratic society, participation is used to ensure equal citizens' rights in community decision-making and public affairs. They prepare their children to be democratic citizens and to express themselves, negotiate their values, and learn to be open to human diversity, communication, and values (Dewey, 1916/1998; Halla Jónsdóttir, 2010; Ólafur Páll Jónsson, 2010).

According to Ólafur Páll Jónsson (2008), participation is appreciated according to what it involves and by its goal. This is a powerful tool used in democratic societies where many opinions compete, and only the majority wins. Understanding the purpose and value of participation is crucial for the parties that did not win to keep participating. Ólafur Páll Jónsson, through Dewey's vision about the means of education, also makes a distinction between social and democratic participation. In social participation, day-by-day interaction between people occurs by using critical thinking and reflection to solve problems, which generates education or knowledge. In the words of Páll Skúlason (1987); education highlights the things that matter, for whom persons should live their lives and how they should live. It teaches men to use their common sense, to use their freedom to shape their own life's attitude and lifestyle. Social participation brings people satisfaction by taking part in resolving issues that matter most to them, making it personal. In democratic participation, people need to view themselves as a part of society, so that what is in society's best interest is also in their own best interest.

Therefore, education is related to democratic participation, as a tool used by democratic societies to make people more capable and competitive to exchange ideas and thrive, not just in the voting process but in sharing ideas in other spheres of knowledge. In this context, the value of democratic participation is also educational, and it brings life satisfaction, hence, the foundation of both social and democratic participation is the same (Ólafur Páll Jónsson, 2008).

Guided participation is a learning process through which children interact with experienced people in relevant social and personal practices of everyday life (Rogoff et al., 1993). It involves assessing, inquiring, and responding (AIR). Finally, the teacher responds in such a way that the child feels motivated to think more about it (Petty, 2009). The environment of the classroom influences the children's experience and their emotional development (Kirk \& Jay, 2018). The effect of interaction is also explained by Vygotsky (1978) who claims that children play, learn, and develop skills simultaneously.

The Icelandic curriculum for preschools affirms that schools must take the responsibility to be a source of knowledge and information for all children, given that some of them do not have this opportunity at home. Children must learn to evaluate situations and make decisions, to practice 
exercising their rights (Mennta- og menningarmálaráðuneytið, 2011). In this context, Lansdown (2001) emphasizes that children learn how their rights and actions affect the rights of others. By doing this, schools protect children against discrimination based on gender, race, religion, sexual orientation, disability, language, nationality, age, class, or culture.

The European Council stipulates that all Member States must support Article 12 of the Convention on children's rights, and to listen to children without discrimination, allowing them to participate according to their age, in building their lives (Council of Europe, 2012).

\section{Values development in the preschool}

Education is a medium to instill values and knowledge in children. According to Páll Skúlason (1987) education is the fruit of one's experience; it does not happen, but it steals into our minds, down into our instincts and character, irrigating them and fertilizing them. It leads men to evolve, allowing their attributes and intelligence to flourish and grow until they die. Values are the foundation of one's attitude toward other humans and controversial issues. They compound the norm that people must evaluate thinking and actions (Puolimatka, 1990; Sigrún Aðalbjarnardóttir, 2007).

Value language is the spoken use of ethical values on a daily basis (Puolimatka, 1990). It has a distinctive nature that makes it personal and enables it to evolve independently. Just as language adapts to reality, it is possible to affirm that value language development is proof of the existence of value reality people have access to experience, talk about and debate (Brandt, 1961). The store of knowledge in each person regarding values is broad, and it empowers children to make their own judgment when they are presented with value experiences. Children develop cognitions of values when they have access to them through interaction (Puolimatka, 1990).

The aims of moral education differ in the literature. According to Puolimatka (1990), its chief aim is to develop clarity and competence to make a person's own system of values, which she can apply in the future; it can also encourage self-evaluation and help individuals take responsibility for outcomes. On the other hand, in a study about Dewey's moral education, Kristján Kristjánsson (2010) explains that ethical education aims to develop both self-respect and respect for others and reinforce behaviors that lead individuals from self-interest to self-control.

According to Puolimatka (1990), when teaching values the teachers' function is to keep in mind individual rights by encouraging children to discover these values by themselves, teaching them to relate values to prior experiences, encouraging them to debate to exchange ideas and to decide on positions through critical thinking. He states that when children use this democratic deliberation, and choose values by themselves, they are more likely commit to them (Puolimatka, 1990). In the same context, Thornberg (2008) mentions that ambiguous and inconsistent rules from the teacher confuse children. According to Puolimatka (1990), the basic method of value education in its affective component is the creation of an atmosphere structured by a value attitude characterized by the commitment to the dignity of persons and their intrinsic value. Findings in a study by Ingibjörg Sigurðardóttir and Jóhanna Einarsdóttir (2016), showed that, while teaching values, preschool teachers needed to use words that children understand, so friendship was used in the sense of being good and being good to friends to clarify values. Children were encouraged to see others' point of view. Furthermore, teachers tried to use words related to values in their discussions with the children.

Puolimatka (1990) considers that teaching values agrees with democratic ways because it strengthens children's individuality and creativity independently. Democratic tools as discussions, and stories, facilitate the exchange of ideas, information, and knowledge. Through discussion and stories, children learn to listen and respect others, and in return, to be listened to and respected (Mennta- og menningarmálaráðuneytið, 2011). Diversity in a democratic society makes the 
education of values indispensable to maintain its principles. Values are part of the fundamental pillars of education, and school subjects should focus on cultivating right attitudes and values (Mennta- og menningarmálaráđuneytið, 2011; Parra Ortiz, 2003; Puolimatka, 1990).

\section{Method}

The methodology used in this study is Action Research (AR), which is a qualitative method of research. The researcher chose the AR method because it is a way of questioning your practice, followed by evaluation, and modification according to the results of the study. This ideology supports education research by encompassing democratic values in its practice (McNiff \& Whitehead, 2002; Roose et al., 2014); hence, the research question I raised was as follows: Does this approach inspire care, respect and participation among the children involved? Furthermore, how can I improve my teaching regarding those democratic values?

Lawrence Stenhouse introduced the idea of the teacher as a researcher who examines his own work and with this examination influences the educational processes. This idea highlights the benefits of education research by encompassing the values of democracy in its practice (McNiff \& Whitehead, 2002; Roose et al., 2014).

$\mathrm{AR}$ as a practice includes "data gathering, reflection on the action as it is presented through the data, generating evidence from the data, and making claims to knowledge based on conclusions drawn from validated evidence" (McNiff \& Whitehead, 2002, p. 16).

The characteristic of AR is that of a cyclic process in which the phases are repeated. Thus, it can be said that the approach of the research is similar to interpretative investigation since there are interactions and changes made during its analysis (Roose et al., 2014). The phases of $\mathrm{AR}$ are, planning, action, evaluation of results, reflection, and the decision on future actions (Kristín Dórarinsdóttir \& Rúnar Sigpórsson, 2016). The researcher is a participant and observer of the action; in an interactive process the knowledge of all participants contributes to the effectiveness of the construction of knowledge through debate, reducing the gap between the author, participants and co-researchers (Nussbaum, 2017; Roose et al. 2014).

The observation and reading of the literature phase of this study took place from February 2018 to January 2019. After observation and having reflected on the children's understanding of values, I decided to do one cycle of four weeks to introduce literature, games and discussions about values through democratic ways. I used three weeks to reflect on and analyze the compiled data in collaboration with my co-researchers. I then conducted three-week cycle research to carry out the new actions. Altogether, the AR was completed in 20 days and 57 sessions from January to March 2019.

\section{The school}

The name of the school in the article is Rabbit Hill, which is a pseudonym for the school so it will not be as recognizable in the data. The researcher worked with the oldest group in the school's six departments, consisting of five to six-year-old children. The school day is divided into four meal breaks, workshops before and after meals, and free time to play inside and outside. My responsibilities in the school are particularly concerned with assemblies, regarding the teaching of children's rights and holding democratic conventions and music. The research was carried out in line of the Icelandic national curriculum guide for preschools that emphasizes the value of democratic and human rights as the pillars of Education (Mennta- og menningarmálaráduneytið, 2011). 


\section{The participants in the research}

The participants in this study, including three critical friends, are called co-investigators who will also verify the data collection.

The core co-investigators in the study were 27 5-6-year-old children with the permission of their parents, their teachers, me included, and the staff members working in the preschool named here as Rabbit Hill. Their positions at Rabbit Hill School are that of principal, and two are responsible for the special education department. The critical friends were one preschool certified teacher in special education; the other holds a degree in psychology studies. These children were chosen as they were the oldest children in the preschool and the material I chose to use was tailored to the age of the children.

The first function of the co-investigators was to be members of a democratic forum where all the voices have the same value, as the Icelandic curriculum implies (Mennta- og menningarmálaráðuneytið, 2011). The second function was to witness the research. The third function of the children was to participate in locating and visualizing the values in the readings and the actions taken through the classes and games. The fourth function was to integrate their critical view and knowledge into the research by participating in the search for definitions of the investigated values. The fifth function was language support that can be needed as I am not a native Icelandic speaker. The sixth function regards the author; that is, to gather all the information and write the thesis. All the functions were executed with excellence.

One boy, Jim, did not use much verbal language, I talked to his parents personally and they authorized his participation in the research. The Director e-mailed the children's parents to present the study to them. Subsequently, I presented each parent with a booklet containing a description of the process and purpose of the study and explained the research.

\section{Collection of data and analysis}

I collected drawings and recordings from the sessions, and data from group interviews with the children, I recorded two meetings with the teachers and gathered teachers' notes and observations. This also included children's interpretations of the concepts during the sessions, testimonies from the colleagues who assisted me and the parents, and my observations of the recording of the sessions. At the end three teachers contributed constructive criticism of my work. Four months after the AR I sent letters to three parents, where I asked for their opinion concerning the research. Triangulation was used to increase the credibility of the research (Sigríður Halldórsdóttir \& Sigurlína Davíðsdóttir, 2016).

The author and co-investigators analyzed the data. The teachers took part in the reflection and constructive analysis of the data during and after the sessions. The teachers and I met twice during the investigation period where we reflected on ways to teach values. The analysis was continuous during the research. Teachers, children's voices and my perception of the sessions directed the actions. Two parents had reflective conversations with me during the research and reviewed the sessions. I regularly talked with the children about their drawings to access their interpretation of the concepts during the nine weeks. The data were analyzed by examining them and highlighting what could be done better and what went well in the process. Reflective conversations with colleagues helped to identify aspects of the data that were important in the work with the children.

\section{Ethics and limitations}

When working with children, it is essential to make clear to them the purpose of the research, what is going to be investigated, what their role is in this research and how long the research 
will last (Jóhanna Einarsdóttir, 2007). There are three principles of ethics that I aimed to fulfil: autonomy, non-maleficence, and beneficence. The principle of autonomy refers to respect for the participants' freedom to participate or not. To ensure that the research was clear to the children, I used a multitude of simple approaches (thumbs up and down sticker, smiles faces, drawings, and puppets), taking into account their body language to express their consent to participate. On the non-maleficence principle, I was careful to maintain their privacy. The material used in Rabbit Hill School for recordings remained in the school during the analysis as Gray \& Winter (2011) recommend. And the names of the children used in this paper are fictitious for protection purposes. As for the beneficence principle, I made sure the children were comfortable, and that they would benefit from their participation (Sigurður Kristinsson, 2016). As Jóhanna Einarsdóttir (2007) reminds us, children are citizens "who hold their own views and perspectives, they have competencies and the right to be heard, and they are able to speak for themselves if the appropriate methods are used."

It may be considered a limitation of this study that the investigation was carried out inside a school, during the class day with a limited number of students. This should be borne in mind when generalizing to other groups or settings. As this is a small group of children, it is not possible to generalize the results to other groups. Nevertheless, one can learn from the researcher's experience and the study shows evidence of how children can be taught democratic values in preschools.

\section{The research}

My position as a foreigner has allowed children to consider it normal when I ask them about the meaning of a word. During observation time in the preschool I asked a girl of five: What is respect? The girl responded, "Respect? I don't know." Later I asked the children as a group and individually about the meaning of respect, care or participation but nobody seemed to understand what I was saying. A teacher and I role-played disrespectful behavior for the children and the children agreed it was wrong. I realized that children knew what respect or care was, but they nevertheless needed to connect the word with the act. I had to relate conceptual knowledge to practical acts that children could identify, and I knew that the key point of my research should be to relate the concepts with the ideas and principles they already have.

In the first cycle of the research the oldest children from two departments were divided into three groups of eight children, four children in each group. They were accompanied to the music room were the data gathering took place by me and one teacher. In the second cycle the construction of the groups changed, and one group was added. Presented below are the findings and analysis of the AR with my reflections on the process and my learning experience. In the description of the research process I chose to describe the action taken and my reflection during the cycles including references to the literature, but different means of presentation are often to be found in the line of action research (McNiff \& Whitehead, 2010).

First cycle

Below is an analysis of the actions I took during the first cycle. I will explain chronologically what led to several changes in methodologies, and how my values came into play in my decisionmaking. Lastly, I will explain what I learned from the actions taken, and the new inquiries that lead me to the second cycle.

In the beginning, I had a meeting with the teachers where I gathered their thoughts regarding respect, care, and participation. The meeting was held a week before the sessions began.

I began the sessions with the children by placing great significance on care, respect, and participation throughout my inquiry. These tenets, as well as democracy, composed the lens 
through which I plotted my course of action for the cycles which followed. This focus guided me throughout my research and helped mold my educational values. My questions at the end of each day were:

- Did I show care, respect?

- Was I active enough?

- If I were 6 years old, would I like a teacher like myself?

From the beginning, the situations in the sessions appeared to me in themes, so I decided to write my thoughts from these themes.

\section{Being true to yourself}

During the first week we worked on the meaning of participation and what it involves. To explain participation to the children I gave them the option on the first day to be part of the research or forego participation. To this end I printed emoji images: smiley faces, thumbs up or down, to attract children's attention, help them to use self-agency and make this step of the research more understandable. Children were given paper and pencil to write their names. The children liked the idea, and it was interesting for them to be part of a research project, so everyone agreed to participate. I started to connect words and acts. We sang and danced to "vindum vindum vefjum band" (wind, wind spin the thread) (Una Margrét Jónsdóttir, 2009) and music which encourages children to dance and play together. The children spoke very little in the sessions in the beginning. Christie (2018) and George (2009) state that children need time and space to learn new things and respecting them involves giving them time to get to know each other and familiarize themselves with the material.

My first action was the result of reading the literature regarding participation. I changed the chosen children's book because it did not fulfill my new understanding of participation. My intention in teaching participation was for children to look at the richness of being and interacting with others as Dewey (1939) and Vygotsky (1978) claim. Reading about values led me to deepen my values perception.

\section{Learning by doing}

Changing material led to the reading of the Convention of the Rights of the Child (United Nations, 1989) that prompted experimenting with creating and learning about rights, and about civic participation.

The second action: Letting children make their own convention for their use of the music room to experience what it is to have a right and participate. For example, the children learned the meaning of the word "rights" by working on their own bill of rights.

We began by finding out the rights we had in the school, such as to walk, to go to the restroom when we needed it, to drink water, to play, to get food if we were hungry. Helping children to realize what they were allowed to do at the school, which was also their right, was easier than trying to explain complex words to the children. Although the literature was not new, the words the children were learning acquired a new meaning in the session context (Dewey, 1916/1998). I learned to be creative and spontaneous and use information from other institutions (Ólafur Páll Jónsson, 2010).

The children discussed their understanding of participation during the AR and in the second week the children drew up their first consideration of values: What is participation? To pick up the garbage, to play with mom and dad, to play with granny and grandpa, to play together in school, to go swimming, to count (because by counting I can get a job when I grow up), to have fun playing with others, to be positive and have friends because when everyone is friends they play together. As seen in Figure 1, Leopold drew what will be his participation in the future. 
Even though Jim spent little time in the sessions, his presence opened the opportunity for a discussion about the rights of equality and care. The reading about Rúnar's sister (Hanna Borg Jónsdóttir, 2016) and the presence of Jim led us to talk about autism. Subsequently, I explained the Icelandic curriculum and its policy regarding special needs students (Ólafur Páll Jónsson \& Póra Björg Sigurðardóttir, 2012). The recording shows that the children are curious about Jim and they used the opportunity to ask about him. By analyzing Jim's condition, we came to the conclusion that care was the motive that allowed Jim to be in the school and participate. The children understood respect as "to obey" and "to be quiet" so when one of the teachers assisting me told them that

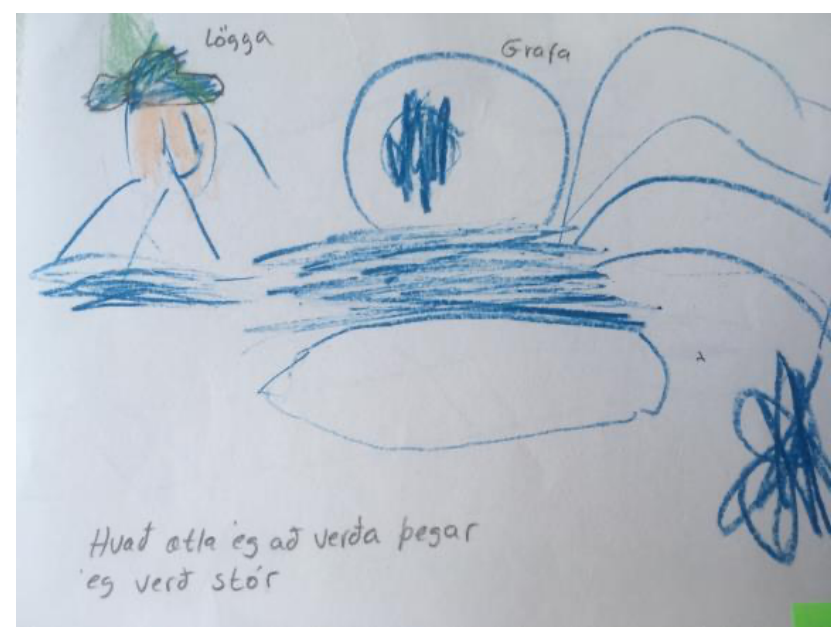

Figure 1. Leopold's contribution to participation by being a policeman and an excavator we had to be quiet when the children were talking to us, the children looked at us in surprise, Benni asked: "Why"? I answered: because we have to respect you".

\section{Dealing with routine}

It was apparent from early on that the children were sensitive to changes in their routine, such as using the music room for these sessions or dealing with teachers they were unfamiliar with. In the first week the children asked me "Why are we here" and they were expecting to go back to their classroom. The children also behaved differently depending on the teacher who assisted me, sometimes being more open and talkative than with others. Furthermore, when the children knew about the sessions early in the day, they were calmer and happier than children who had not known about the sessions beforehand. Maslow (1943) mentions that children need a wellestablished routine because it gives them security. The study from Christie shows that respecting the daily routine and talking with the children about daily activities is a sign of care and respect (Christie, 2018). So, I understood that a change of environment influenced children's behavior and secondly that preparing children involved fairness and was a part of their democratic rights.

\section{Breaking the concepts into simpler words}

The actions carried out in the AR created the themes. This theme is about the first obstacle I found in the research: vocabulary. The children had difficulty understanding the concepts, so I began scaffolding as Burchinal (2018) recommends, starting with words with similar meanings that the children understood, and working slowly up to more complicated words.

Putting the concepts into simpler words using a constructivist approach led to the use of phrases like, to be kind, to be good, and to be friendly. While doing this, I used the words in different contexts to ensure that the children understood, as advised by preschool teachers in Ingibjörg Sigurðardóttir and Jóhanna Einarsdóttir (2016). I needed to make sure all members of the group had the same vocabulary so all the children would understand what I was talking about and we could have a conversation. The children were learning a new feature of language called value language; their understanding of abstract concepts grew as they practiced this value language. In the beginning, if I asked, "What is respect?" They just said, "I do not know". In the third week the children were asked to draw "care". Kristin drew her family, I asked her how this was caring, and she told me "I care about my family". 


\section{Participation and focus}

My fourth action was participating more with the children. I tried not to sit for extended periods, but to engage more with what the children were saying or doing. I used guided participation tools (Rogoff et al., 1993) such as listening to them when they were playing or during discussions, being ready to help them if they needed a word or a behavioral recommendation. Participation was my favorite issue throughout the AR; the meaning of participation within the school context was a big lesson for me.

My fifth action was shortening the length of the literature to highlight the state of mind of the illustrations. I replaced the readings with shorter, more profound texts and stronger characters following the lines from O'Sullivan (2004), hoping to see the children develop their empathy (Upright, 2002). These changes were meant to decrease reading time and make room for more talking, engagement, and critical thinking.

\section{Negotiating}

Negotiation served as a tool to smooth over disagreements and it was handled with care as the children worked on finding the right gestures and words to express or understand one another's emotions (Sennett, 2003). Occasionally their conclusion agreed with mine, but not always.

When the children and I disagreed about the meaning of a word I waited for them to bring up a clear event, word, or emotion from their own experience so they could understand me, or I could understand them. Negotiation involved the exchange of ideas where the children had the opportunity to present their point of view while playing or discussing society, as they developed their character in the context of a democratic society (Dewey, 1916/1998; Ólafur Páll Jónsson, 2010). Negotiating with the children helped me to know them better and through hearing their explanations during the discussions I was able to better understand their motivations in the way research indicates (George, 2009; Ólafur Páll Jónsson \& Dóra Björg Sigurðardóttir, 2012). The children said they felt respected during negotiations and their teachers reported that their self-esteem seemed to be growing; this is in agreement with previous studies on the effects of negotiation in an educational setting (Sigrún Aðalbjarnardóttir, 2007; Thornberg, 2008).

\section{Constructing their value system}

The children comprehended values when they started to relate them to their experience as Dewey (1916/1998) posits; they put words to their emotions by talking about them and their friends' emotions (Poole et al., 2005). By evaluating their emotions, children chose what the right feeling was for each value and worked on their own individual value system as Puolimatka (1990) and Parra Ortiz (2003) recommended. They explored respect, care, and participation

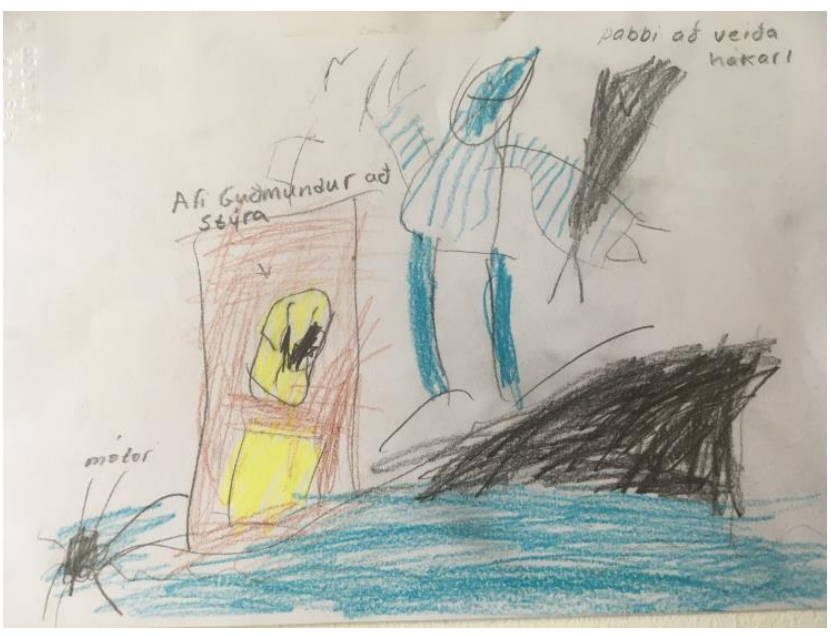

Figure 2. Leopold's grandfather saving the shark as well as related concepts such as tolerance, empathy, violence or bullying, thus having the opportunity to check their thoughts with contrast values as recommended by the preschool teachers (Ingibjörg Sigurðardóttir \& Jóhanna Einarsdóttir, 2016).

To clarify, I would say that when we deliberated and agreed about values, we found a common ground, or as Dewey would say, a common value that identified us as a community (Dewey, 1916/1998). The children also had the opportunity, through readings and discussions, to explore other people's emotions and rights. I asked one how he would feel if no one wanted to be his friend, and he answered quickly: "I would 
feel very sad; I would not like it." I asked openly: "What would we say to our friend who feels bad because someone died in her family?" Fredrik: "I would invite her to play with me." Kristin: "I would invite her to be with us." Gloria: "I would invite her to play with me." By stepping into one another's shoes, the children found meaning in their emotions and the values started to become clear. Values are a two-way relationship; it was good for the children to reinforce selfrespect and self- care which led them to respect and care for others (Banks, 2004; Ólafur Páll Jónsson \& Póra Björg Sigurðardóttir, 2012).

My next action was listening and validating the children's words. Telling the children that they were right made them feel that their words were worthy and that they are entitled to their own opinion. The children did not speak very much, but they were clear when agreeing and disagreeing with what was being said. The terms of care, participation and respect started to have a new dimension that the children were bringing to the sessions. We discussed the need to pick up garbage from the street and asked them how they saw it. Some children regarded that as respect for the city, keeping it clean; while others looked at it as an act of care about their surroundings. A third party said it was participation. Confronting them with other views was important to the objective of democracy and I wanted the children to train their language skills so they would be able to defend their ideas.

One example of their value recognition is from the third week. Leopoldo told us a story about his grandfather saving a shark. That day, I asked the children to draw a picture of care. When Leopoldo approached me to discuss his drawing (Figure 2) he explained, that what he felt for his shark was care for nature. I encouraged him to think about sympathy (i. samúð). He agreed that while it can be sympathy, it is also respect and he drew a picture showing his grandfather saving the shark. Another example is Haraldur who wanted to be sure that lending someone a ball was respect. I told him that my understanding was care but he defended his view. These opinions combined with the drawings revealed that children's intentions, understanding, and perspectives were clear to them and that they were in control of what they thought and how they expressed themselves, both verbally and in their drawings (Cox, 2005). They had the last word when interpreting their drawings, and I listened and recorded them. In this way, the children had a say in the sessions and began to be more active in their drawings and the stories behind them. Caro is a good example of this. She mentioned that her feelings toward nature were those of care and not love, a feeling reserved for her mother.

\section{Reflection time}

I held a meeting with all the teachers to reflect on the outcomes. The teachers shared their reflections about the concepts. Their insight about the AR was that it had a positive influence on the children because of the good things they had the opportunity to do, that the research enriched their day in a meaningful way. The children revealed a change in their behavior. They were happier, they showed more kindness to one another and more respect to the teachers. I made up short stories, which contained those themes. I asked the children what they wanted for the next cycle and they answered: fun.

For the second cycle I reduced their session time to 15 minutes. I increased games and play that supported personal expression and reduced the groups from eight to six children. I attempted to reduce the teacher-power by levelling to their role in the games. For example, I used the children's chair so I would be at their level and they did not have to look up but had direct eye contact. In addition, I monitored myself to remind me to applaud the children five times over the 15 minutes, and to highlight the good things they did.

Second cycle

Here I examine the AR as a whole to highlight what I learned and how the actions influenced the development of the children's perception of values. 
Focus on playing and following the game

Based on the Icelandic curriculum (Mennta- og menningarmálaráðuneytið, 2011) and Lansdown (2001) regarding letting children evaluate situations and make decisions, I created stories and asked the children to evaluate them. This came with a twist since I created them to reflect my opinion. I let the children know this beforehand, including the fact that the purpose of the stories was to share values with other children.

Following the children's lead, the sessions turned into a game, making them more cheerful. By changing the focus, the recordings show that the sessions were fun and interesting. The game was supposed to promote social and individual learning as Beatty (2017) mentions in her article about high hopes for play. Children learned about their rights and those of others by participating and playing the game (Lansdown, 2001). We explored the right to have a family, the right to have an education, the right to have a name, the right to be fed, the right to medical help, the right to have a house, and the right to participation.

Next, we explored contrasting options as Gunnlaugur Sigurðsson (2016) proposed. For example, running in the corridors is essentially prohibited but reflecting on what could happen if we run and fall down gave us the opportunity to see if there was actually a valid reason for the rule. By the final week the children easily talked about respect, care and participation. They discussed their opinions about sharing goods with other nations and they would judge actions in the classroom or in the stories. The teachers and I were careful not to break the rhythm of the conversation, trying to be just an asset to the children and acting as guides (Gunnlaugur Sigurðsson, 2016).

\section{Looking out of the school walls}

The children were proud and happy to hear how Iceland helps other nations and how this action is linked with participation and care. I introduced the names of Icelandic institutions that work in global service. Children were curious about children in other nations. They showed that they cared by giving ideas for helping and sharing goods, food, and schooling. We reflected on these subjects for two weeks, and it gave them a global picture of care and respect. The children's comments and curiosity about other children's needs showed more sensitiveness in the way that Banks (2004) mentions, and their insight into the global context of democracy increased.

I analyzed all the features of participation and how I could include them in my educational model. Participation for most people is being with others, taking part in events, voting, and so forth. By singling out the word, it became up to me as a teacher taking part in what they were doing and being present for them. This was a mode of the democratic participation described by Ólafur Páll Jónsson (2008).

\section{Mastering the meaning with drawings}

Children drew more than they spoke. The drawings developed with the sessions. In the end, the children drawings were more elaborate and with a great deal of content. The children used drawings to negotiate their emotions and problems. Pall was afraid of monsters. He said: "The monster has a respect for space and thinks well of it. The monster can see through the buildings and planets." In another drawing, Peter considered respect as the way to fix their differences. In his drawing he explained, "This is my friend, he has more blocks than me, I only have two, [then he showed me the other side of the paper] he is going to give me one block to play with." I think Peter's case is a good example of what Cox (2005) mentions: the focus of drawing was not on the drawing but on his relationship with his friend.

Narrative was a strong tool that helped children to manipulate their thoughts (Bruner, 1996) in the drawings and their translations. In the last sessions the children found it easier to translate their understanding of concepts into words and I had the opportunity to better understand their insights and perceptions of values. Carol drew a monster and a girl and when I asked 
her about this, she said: "It is a good monster, it respects the children by being funny." I asked her, "How can he be funny?" She said, "It plays with her and talks nice to her when they don't agree about something." Then I asked, "Do you mean that to respect people is to be funny with them?" She said, "Yes, otherwise people are boring." Another drawing that clearly explains how children perceive care and respect is the one by Maria (see Figure 4). What she had to say about it was: "This is a flower and the sun, they are friends, the flower wanted to make circles to not burn. But it could not do it because it was stuck on the ground. There was a rainbow that came between them, so the sun did not burn the flower because the rainbow protected it."

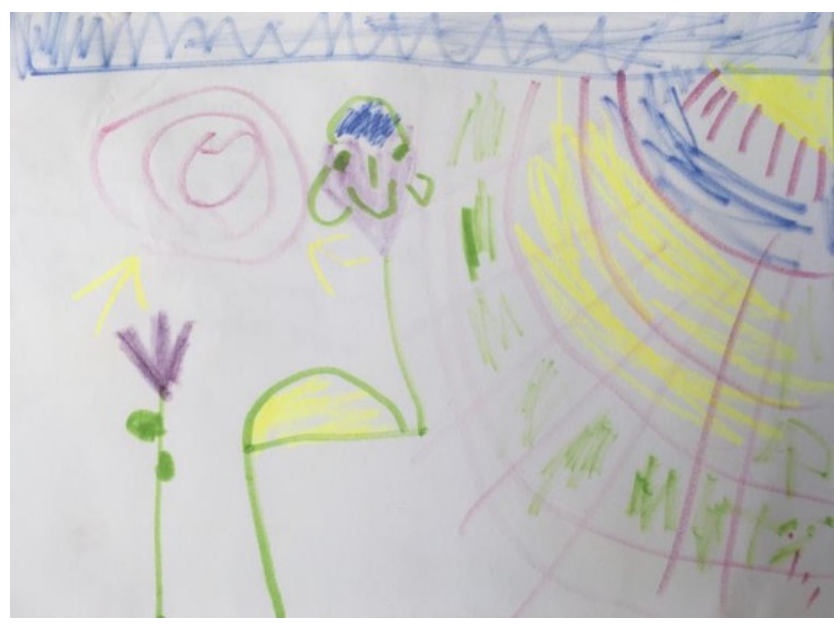

Figure 3 Maria's story of the flower

\section{After the AR}

Two weeks after the end of the AR the children were asked to describe a teacher who respects them. Six girls and six boys understood the terms and gave clear answers. Some of the girls' answers were: The teacher should talk nice to me. She should not hurt me or shout at me. She should hug me sometimes. She should play with me. Some of the boys' answers were: She should teach many games. She should not yell at the children. She should not hug if children do not want a hug.

After the action research Rabbit Hill preschool established a weekly teaching of the values and rights of the child as part of its school schedule. This goes by the name of Barnasáttmáli and is arranged in collaboration with the municipality of Kópavogur. Moreover, the preschool holds a weekly congress (i. barnaping) where children have the opportunity to express their opinions about daily issues of the school. These two new practices follow the model used in this study.

\section{Conclusion}

To sum up, the research into the improvement of my teaching regarding values, caused me to reflect on the definition of care, respect and participation inspired by Dewey's educational theory, and its use in educational settings. Choosing the AR method aided me in conducting an effective and flexible daily research program and in acquiring an objective approach to the evaluation of my teaching. When the sessions started the children did not talk much but at the end of the project, they had gained sufficient vocabulary to have democratic interactions and share their opinions, thus corroborating the assertion that children are experts and capable of expressing their own thoughts. Language became an asset by showing the children a value language that we scaffolded as a group, following the children's pace throughout the sessions. Drawing helped the children to display their awareness of the values, levelling the playing field by giving them all the same means to express themselves. The drawings also allowed me to see how their understanding grew and changed. The results indicate that when the teacher embraces educational values in her daily behavior she is acting in accordance with a democratic environment and education. Therefore, modeling and demonstrating educational values is a fitting tool to teach democratic values to 5-6-year-old children. These values involve preserving the children's right to individuality as emphasized in the Icelandic curriculum. Therefore, the answer to my research question as to how to improve my teaching of democratic values is by using encouraging ways to promote democratic solutions to address daily issues. This procedure changes the children's awareness of values, always ensuring that the child enjoys the appropriate respect, care and opportunity to participate. Furthermore, it was noted that it is important to 
use cheerfulness and humor that children can relate to. This method will make the process easier and more enjoyable for everyone involved. Using the vocabulary of values (i.e. value language) in different contexts, relating them to emotions that ascribe meaning to their rights by linking them to democratic values, helps the children towards clarity and understanding of the concepts concerned. The main changes in my teaching from the beginning to the end of the research were adding those values to my own behavior and my instructions to the children and co-workers and thus finding a way to help the children to recognize their rights. Hoping, as Páll Skúlason (1987) explained, that the instruction of values will filter into their minds, into their instinct and character, irrigating and fertilizing them; thus helping the children to evolve and their attributes and intelligence to flourish.

\section{„Ég mundi bjóða henni að leika með mér“ Starfendarannsókn í leikskóla}

Dessi grein segir frá starfendarannsókn sem var hluti af meistaraverkefni við Háskólann á Akureyri. Rannsóknin hafði pað að markmiði að auka hæfni mína til að kenna ungum börnum lýðræðisleg gildi. Ég leitaðist við að finna heppilegar kennsluaðferðir og fór rannsóknin fram í einum leikskóla á höfuðborgarsvæðinu. Rannsóknin var unnin með hópi 5-6 ára barna, níu kennurum auk rannsakandans. Kennsluaðferðir próuðust á meðan á rannsókninni stóð m.a. með pví að rýna í eigin aðferðir auk pess sem kennarar og börn mátu gæði kennslustundarinnar hverju sinni. Einnig var markvisst unnið að pví að auka sjálfsmynd barnanna og ræða við börnin um lýðræðisleg gildi í daglegu starfi.

Í rannsókninni var áhersla lögð á aðferðir sem voru börnunum kunnugar, p.e. hugmyndir og efni úr sérkennslu voru nýttar sem og leikur, bæði frjáls og skipulagður. Börnin teiknuðu einnig myndir til að deila eigin skoðunum og upplifun er sneri að gildum eins og virðingu, vináttu og fjölskyldu. Starfendarannsóknin var virkt og skapandi ferli; hver kennslustund var ígrunduð daglega að henni lokinni, til að meta hvort hún skilaði árangri eða ekki, og einnig hvernig bæta mætti áherslur og vinnulag daginn eftir. Ég skráði ferlið og pær breytingar sem áttu sér stað í hverri viku og flokkaði jafnframt eftir pemum. Viðmiðin sem fylgt var voru að börnin og kennararnir deildu eigin skoðunum í gegnum samræur; að próun væri í kennslustundunum; að börn yrðu opnari við að deila og tjá mat sitt á atburðum og peim sögum eða textum sem voru nýtt í kennslunni. Börnin voru pátttakendur í pví ferli að próa og meta hvernig til tókst og hvað betur mátti fara. Samtöl við pau og pátttaka peirra voru hreyfiafl rannsóknarinnar.

Niðurstöðurnar gefa jákvæðar vísbendingar um að hæfni mín til kennslu á pessum gildum hafi orðið betri og markvissari með pví að nota lýðræðisleg vinnubrögð, klípusögur, gleði og hvatningu í skólastofunni. Sýndu börnin án vafa framfarir í lýðræðislegum vinnubrögðum.

Rannsóknin sýnir fram á að mikilvægt er að jafnvægi sé í valdatengslum milli kennara og barna svo börnin upplifi sjálfræði sitt. Einnig að gott er að útskýra smátt og smátt lýðræðisleg gildi með pví að tengja pau við klípusögur og daglegt starf leikskólabarna pannig að börnin viti út á hvað lýðræði gengur og til hvers er ætlast af peim. Tilvalið er að pjálfa lýðræðisleg vinnubrögð í barnahópnum í frjálsum leik og sköpun. Degar börnin upplifa virðingu frá öðrum, eru pau líklegri til að svara í sömu mynt. Börnin eiga að upplifa pátttökurétt svo að pau geri sér grein fyrir eigin getu og prói með sér hæfileika til að stýra hugmyndum sínum á lýðræðislegan hátt. Degar börnin skynja velvild og virðingu frá kennaranum eru pau líklegri til að svara í sömu mynt. Út frá sjónarmiðum barnanna í rannsókninni er kennari sá sem sýnir virðingu, einhver sem er góður, talar fallega til barnanna og leikur sér fallega með peim. 
Greinin segir frá hluta rannsóknarinnar, sem sýnir ávinning af pví að innleiða lýðræðisleg gildi í starfi með börnum í ljósi kenningar Johns Dewey. Börnin settu fram hugmyndir um gildi og merkingu peirra í samfélaginu. Dau lýstu einnig yfir áhuga á að vera pátttakendur í málefnum peirra, sem eru peim kær. Jafnframt varpar greinin ljósi á hvernig starfendarannsóknin eykur meðvitund mína um nám og kennslu barnanna er snýr að pví að kenna gildi og efla pátttöku peirra á lýðræðislegan hátt. Leikskólinn hefur haldið áfram að vinna með áherslur sem vekja börn til vitundar um lýðræðisleg gildi og haldnir eru fundir par sem elstu börnin koma reglulega saman til að ræða málefni sem varða hagsmuni peirra.

Lykilorð: Lýðræði, virðing, umhyggja, pátttaka, starfendarannsókn

\section{Um höfundana}

Patricia Segura Valdes (patriciasvaldes@gmail.com) starfar sem sérkennari við leikskólann Læk. Hún lauk B.A.-prófi í spænsku og hlaut kennsluréttindi fyrir grunn- og framhaldsskóla frá Háskóla Íslands árið 2007. Hún lauk M.A.-prófi í menntavísindum með áherslu á sérkennslu frá Háskólanum á Akureyri árið 2019. Rannsóknir hennar hafa einkum beinst að réttindum barna og próun leiða til að kenna börnum um lýðræðisleg gildi.

Jórunn Elídóttir (je@unak.is) er dósent við kennaradeild hug- og félagsvísindasviðs Háskólans á Akureyri. Hún er leikskólakennari, lærði sérkennslufrææi í Noregi (19831988) og lauk doktorsprófi í sérkennslufræðum frá Worcester University 2002. Hún var á árum áđur leikskólasérkennari, sérkennari og sérkennsluráđgjafi í grunnskólum. Kennslu- og rannsóknarsvið hennar eru skóli án aðgreiningar, sérkennslufræði, leikskólafræði og málefni er varða ættleidd börn.

\section{About the authors}

Patricia Segura Valdes (patriciasvaldes@gmail.com) works as a special education teacher at the Preschool Lækur (Kópavogur/Iceland). She completed a BA degree in Spanish from the University of Iceland, a diploma in pedagogy for elementary and high school education from the University of Iceland in 2007 and an MA in science education from the University of Akureyri in 2019. Her research has mainly focused on developing methodologies for the teaching of democratic values and children's rights in education settings.

Jórunn Elídóttir (je@unak.is) is a senior lecturer at the Faculty of Education, School of Humanities and Social Sciences, University of Akureyri. She is an early childhood teacher, studied special education in Norway (1983-1988) and completed a PhD in special education from Worcester University in 2002. She has been a special preschool teacher as well as a specialist teacher and counsellor in special education at the compulsory school level. Her research interests concern special education, inclusive education, early childhood education and adopted children. 


\section{References}

Banks, J. A. (2004). Teaching for social justice, diversity, and citizenship in a global world. The Educational Forum, 68(4), 296-305. https://doi.org/10.1080/00131720408984645

Banks, J.A., Cookson, P., Gay, G., Hawley,W. D., Jordan, J. I., Nieto, S., Schofield, J.W., \& Stephan, W. G. (2001). Diversity within unity: Essential principles for teaching and learning in a multicultural society. Phi Delta Kappan, 83(3), 196-207. https://doi.org/10.1177\%2F003172170108300309

Beatty, B. (2017). John Dewey's high hopes for play: Democracy and education and progressive era controversies over play in kindergarten and preschool education. The Journal of the Gilded Ages and Progressive Era, 16(4), 424-437. https://doi.org/10.1017/S1537781417000317

Brandt, R. B. (1961). Value and obligation: Systematic readings in ethics. Harcourt, Brace \& World.

Bruner, J. S. (1996). The culture of education. Harvard University Press.

Burchinal, M. (2018). Measuring early care and education quality. Child Development Perspectives, 12(1), 3-9. https://doi.org/10.1111/cdep.12260

Christiano, T. (2006, July 27). Democracy. In E. N. Zalta (Ed.), The Stanford Encyclopedia of Philosophy (Fall 2018 ed.). https://plato.stanford.edu/entries/democracy/

Christie, T. (2018). Respect: The heart of serving infants and toddlers. YC Young Children, 73(3), 10-15. https://search.proquest.com/docview/2059127968? accountid=27513

Council of Europe. (2012). Council of Europe Strategy for the rights of the child (2012-2015). https://rm.coe. int/CoERMPublicCommonSearchServices/DisplayDCTMContent?documentId=09000016805a920a

Cox, S. (2005). Intentions and meaning in young children's drawing. International Journal of Art \& Design Education, 24(2), 115-125. https://doi.org/10.1111/j.1476-8070.2005.00432.x

Cureton, A. (2013). From self-respect to respect for others. Pacific Philosophical Quarterly, 94(2), 166-187. https://doi.org/10.1111/j.1468-0114.2012.01450.x

Dahl, R.A. (2020). Democracy. Encyclopcedia Britannica. https://www.britannica.com/topic/democracy/Democratic-institutions

Davies, L. (1999). Comparing definitions of democracy in education. Compare, 29(2), 127-140. https://doi. org/10.1080/0305792990290203

Dewey, J. (1998). Democracia y educación: Una introducción a la filosofía de la educación (3rd ed.). Ediciones Morata. (Original work published 1916)

Dewey, J. (1939). Creative democracy: The task before us. https://www.philosophie.uni-muenchen.de/studium/ das_fach/warum_phil_ueberhaupt/dewey_creative_democracy.pdf

Dewey, J. (2010). Sannfæring mín um menntun [My conviction on education] (Gunnar Ragnarsson, Trans.). In Jóhanna Einarsdóttir \& Ólafur Páll Jónsson (Eds.), John Dewey í hugsun og verki: Menntun, reynsla og lýdrąi [John Dewey in reflection and action: Education, experience and democracy] (pp. 169-180). Háskólaútgáfan. (Original work published 1897)

Fleer, M. (2011). 'Conceptual Play': Foregrounding imagination and cognition during concept formation in early years education. Contemporary Issues in Early Childhood, 12(3), 224-240. https://www.researchgate. net/journal/14639491_Contemporary_Issues_in_Early_Childhood

George, S. (2009). Too young for respect? Realizing respect for young children in their everyday environments. A cross-cultural analysis (ED522534). https://files.eric.ed.gov/fulltext/ED522534.pdf

Gheaus, A. (2018, September 4). Personal relationship goods. In E. N. Zalta (Ed.), The Stanford encyclopedia of philosophy (Fall 2018 Ed.). https://plato.stanford.edu/entries/personal-relationship- goods/

Gray, C., \& Winter, E. (2011). Hearing voices: Participatory research with preschool children with and without disabilities. European Early Childhood Education Research Journal, 19(3), 309-320, https://doi.org/10.1 080/1350293X.2011.597963

Gunnar E. Finnbogason. (2010). Samfélag - skóli - einstaklingur: Helstu uppeldis- og menntahugmyndir John Dewey [Community - school - individual:John Dewey's main ideas on pedagogy and education]. In Jóhanna Einarsdóttir \& Ólafur Páll Jónsson (Eds.), John Dewey í hugsun og verki: Menntun, reynsla og l'́y rææi [John Dewey in reflection and action:Education, experience and democracy] (pp. 43-56). Háskólaútgáfan. 
Gunnlaugur Sigurðsson. (2016). Lýðræði í frjálsun leik barna [Democracy in children’s free play]. Netla Veftímarit um uppeldi og menntun. http://netla.hi.is/greinar/2016/ryn/13_ryn_arsrit_2016.pdf

Halla Jónsdóttir. (2010). Lýðræði og samræða [Democracy and dialogue]. In Jóhanna Einarsdóttir \& Ólafur Páll Jónsson (Eds.), John Dewey í hugsun og verki: Menntun, reynsla og lýdræði [John Dewey in reflection and action: Education, experience and democracy] (pp. 131-144). Háskólaútgáfan.

Hanna Borg Jónsdóttir. (2016). Rúnar góði [Rúnar the Good]. Salka.

Henry, A. (2010). Race and gender in classrooms: Implications for teachers. In J. A. Banks \& C. A. M. Banks (Eds.), Multicultural education: Issues and perspectives (pp. 183-207). Wiley.

Ingibjörg Sigurðardóttir \& Jóhanna Einarsdóttir. (2016). An action research study on an Icelandic preschool: Developing consensus about values and values education. International Journal of Early Childhood, 48(2), 161-177. https://doi.org/10.1007/s13158-016-0161-5

Jóhanna Einarsdóttir, Puroila, A., Johansson, E. M., Broström, S., \& Emilson, A. (2015). Democracy, caring and competence:Values perspectives in ECEC curricula in the Nordic countries. International Journal of Early Years Education, 23(1), 97-114. https://doi.org/10.1080/09669760.2014.970521

Jóhanna Einarsdóttir. (2007). Research with children: Methodological and ethical challenges. European Early Childhood Education Research Journal, 15(2), 197-211. https://doi.org/10.1080/13502930701321477

Jón Torfi Jónasson. (2006). Frá gaslu til skóla: Um próun leikskóla á Íslandi [From childminding to school: On the development of Icelandic preschools]. Félagsvísindastofnun Háskóla Íslands.

Kant, I. (1996). Groundwork of the metaphysics of morals (M. Gregor, Trans.). Cambridge University Press. (Original work published 1785).

Kirk, G., \& Jay, J. (2018). Supporting kindergarten children's social and emotional development: Examining the synergetic role of environments, play, and relationships. Journal of Research in Childhood Education, 32(4), 472-485. https://doi.org/10.1080/02568543.2018.1495671

Kristín Dýrfjörð. (2006). Lýðræði í leikskólum: Um viðhorf leikskólakennara [Democracy in preschools: On the perspectives of preschool teachers]. Netla - Veftimarit um uppeldi og menntun. http://netla.hi.is/ greinar/2006/009/index.htm

Kristín Dórarinsdóttir \& Rúnar Sigpórsson. (2016). Starfenda- og pátttökurannsóknir [Action and participatory research]. In Sigríður Halldórsdóttir (Ed.), Handbók i aðferðafreæi rannsókna [Manual on research methodology] (pp. 347-360). Háskólinn á Akureyri.

Kristján Kristjánsson. (2010). Siðfræði, siðferðilegt sjálf og siðferðilegt uppeldi í verkum Deweys [Ethics, the ethical self and ethical parenting]. In Jóhanna Einarsdóttir \& Ólafur Páll Jónsson (Eds.), John Dewey $i$ hugsun og verki: Menntun, reynsla og lýdraði [John Dewey in reflection and action: Education, experience and democracy] (pp. 89-106). Háskólaútgáfan.

LaCelle-Peterson, M., \& VanFossen, P. J. (1999). Creative democracy and teacher education:The task before us. Education and Culture, 15(1), 1-8. https://docs.lib.purdue.edu/eandc/vol15/iss1/art2/

Lansdown, G. (2001). Promoting children's participation in democratic decision-making (ED452121). https://eric. ed.gov/?q=ED452121\&id=ED452121

Lovatt, D., \& Hedges, H. (2015). Children's working theories: Invoking disequilibrium. Early Child Development and Care, 185(6), 909-925. https://doi.org/10.1080/03004430.2014.967688

Marchand, H. (2012). Contributions of Piagetian and post-Piagetian theories to education. Educational Research Review, 7(3), 165-176. https://doi.org/10.1016/j.edurev.2012.04.002

Maslow, A. H. (1943). A theory of human motivation. Psychological Review, 50(4), 370-396. https://doi.apa. org/doi/10.1037/h0054346

McNiff, J., \& Whitehead, J. (2002). Action research: Principles and practice. RoutledgeFalmer.

McNiff, J., \& Whitehead, J. (2010). You and your action research project (3rd ed.). Routledge.

Mennta- og menningarmálaráðuneytið [Ministry of Education, Science and Culture]. (2011). Aðalnámskrá leikskóla 2011 [The Icelandic national curriculum guide for preschool]. https://www.stjornarradid.is/ verkefni/menntamal/namskrar/

Merriam-Webster. (n.d.). Participation. In Merriam-Webster.com dictionary. Retrieved February 7, 2020, from https://www.merriam-webster.com/dictionary/participation 
Noddings, N. (2005). Caring in education. In M. K. Smith (Ed.), The encyclopedia of informal education. www. infed.org/biblio/noddings_caring_in_education.htm

Noddings, N. (2010). Moral education in an age of globalization. Educational Philosophy and Theory, 42(4), 390-396. https://doi.org/10.1111/j.1469-5812.2008.00487.x

Nussbaum, L. (2017). Doing research with teachers. In E. Moore \& M. Dooly (Eds.), Qualitative approaches to research on plurilingual education (pp. 46-67). https://files.eric.ed.gov/fulltext/ED573595.pdf

O’Sullivan, S. (2004). Books to live by: Using children's literature for character education. The Reading Teacher, 57(7), 640-645. https://search.proquest.com/docview/203282698?accountid=27513

Ólafur Páll Jónsson. (2008). Lýðræði, menntun og pátttaka [Democracy, education and participation]. Netla - Veftimarit um uppeldi og menntun. http://netla.hi.is/greinar/2008/013/

Ólafur Páll Jónsson. (2010). Hugsun, reynsla og lýðræði [Reflection, experience and democracy]. In Jóhanna Einarsdóttir \& Ólafur Páll Jónsson (Eds.), John Dewey í hugsun og verki: Menntun, reynsla og lýdræði [John Dewey in reflection and action: Education, experience and democracy] (pp. 13-41). Háskólaútgáfan.

Ólafur Páll Jónsson. (2016). Democratic and inclusive education in Iceland: Transgression and the medical gaze. Nordic Journal of Social Research, 7, 77-92. https://doi.org/10.7577/njsr.2097

Ólafur Páll Jónsson \& Póra Björg Sigurðardóttir. (2012). Lýðræði og mannréttindi: Grunnpáttur í menntun á öllum skólastigum [Democracy and human rights: A fundamental aspect of education at all school levels]. In Aldís Yngvadóttir \& Sylvía Guðmundsdóttir (Series Eds.), Ritröð um grunnpatti menntunar [A series of publications on the fundamentals of education]. Mennta- og menningarmálaráduneytið.

Parra Ortiz, J. M. (2003). La educación en valores y su práctica en el aula. Tendencias Pedagógicas, 8, 67-88. https://doi.org/10.15366/tp

Páll Skúlason. (1987). Palingar [Conjectures]. Ergo.

Páll Skúlason. (1990). Siðfræði [Ethics]. Birtingur.

Petty, K. (2009). Using guided participation to support young children's social development. Young Children, 64(4), 80-85. https://search.proquest.com/docview/197648532?pq-origsite=gscholar

Piaget, J. (1950). The psychology of intelligence (M. Piercy \& D. E. Berlyne, Trans.). Routledge.

Piaget, J. (1954). The development of object concept (M. Cook, Trans.). In J. Piaget \& M. Cook (Eds.), The construction of reality in the child (pp. 3-96). Basic Books.

Poole, C., Miller, S. A., \& Church, E. B. (2005). How empathy develops: Effective responses to children help set the foundation for empathy. Early Childhood Today, 20(2), 21-25. https://eric.ed.gov/?id=EJ726353

Puolimatka, T. (1990). Pluralism and education in values (ED406244). ERIC. https://eric.ed.gov $/$ ?q=ED406244\&id=ED406244

Rogoff, B., Mistry, J., Goncu, A., \& Moiser, C. (1993). Guided participation in cultural activity by toddlers and caregivers. Monographs of the Society for Research in Child Development, 58(8), v-179. https://doi. org/10.2307/1166109

Roose, R., De Bie, M., \& Roets, G. (2014). Action research and democracy. In G. Biesta, M. De Bie, \& D. Wildemeersch (Eds.), Civic learning, democracy citizenship and the public sphere (pp. 107-121). Springer.

Sennett, R. (2003). Respect: The formation of character in a world of inequality. Penguin.

Sigríður Halldórsdóttir \& Sigurlína Davíðsdóttir. (2016). Réttmæti og áreiðanleiki í megindlegum og eigindlegum rannsóknum [Correctness and reliability and quantitative and qualitative research]. In Sigríður Halldórsdóttir (Ed.), Handbók i aðferðafreði rannsókna [Manual on research methodology] (pp. 211-227). Háskólinn á Akureyri.

Sigrún Aðalbjarnardóttir. (2007). Virðing og umhyggja:Ákall 21. aldar [Respect and care:A 21st century appeal]. Heimskringla, háskólaforlag Máls og menningar.

Sigurður Kristinsson. (2016). Siðfræði rannsókna og siðanefndir [Research ethics and ethics committees]. In Sigríður Halldórsdóttir (Ed.), Handbók i a đferðafraði rannsókna [Manual on research methodology] (pp. 71-88). Háskólinn á Akureyri.

Skrifstofa Alpingis. (2018). Alpingi. https://www.althingi.is/pdf/Althingi2018_islenska.pdf 
Thornberg, R. (2008). Values education as the daily fostering of school rules. Research in Education, 80(1), 52-62. https://doi.org/10.7227\%2FRIE.80.5

Una Margrét Jónsdóttir. (2009). Allir í leik: Söngvaleikir barna [All must join in: Singing games for children]. Æskan.

United Nations Committee on the Rights of the Child. (2006). A guide to general comment 7: Implementing child rights in early childhood. https://www.unicef.org/earlychildhood/files/Guide_to_GC7.pdf

United Nations. (1989). Multilateral: Convention on the rights of the child. Treaty Series, 1577,3-178. https:// doi.org/10.18356/4e5e0483-en-fr

Upright, R. L. (2002).To tell a tale:The use of moral dilemmas to increase empathy in the elementary school child. Early Childhood Journal, 30(1), 15-20. https://doi.org/10.1023/A:1016585713774

Valborg Sigurðardóttir. (1998). Fósturskóli Íslands. Gott mál.

Vygotsky, L. S. (1978). Mind in society: The development of higher psychological processes. Harvard University Press.

Patricia Segura Valdes and Jórunn Elídóttir. (2020).

"I would invite her to play with me": Fostering respect, care and participation in a preschool an action research project.

Netla - Veftímarit um uppeldi og menntun. Menntavísindasvið Háskóla Íslands.

Sótt af http://netla.hi.is/greinar/2020/ryn/09

DOI: https://doi.org/10.24270/netla.2020.9 